\title{
Prospective study on outcomes of postpartum intrauterine contraceptive device including safety, efficacy and expulsion at GMERS Medical College, Dharpur-Patan, Gujarat, India
}

\author{
Parul S. Jani*
}

Department of Obstetrics and Gynecology, Gujarat Medical Education and Research Society Medical College, Dharpur, Patan, Gujarat, India

Received: 01 May 2018

Accepted: 23 June 2018

*Correspondence:

Dr. Parul S. Jani,

E-mail: paruparelia@yahoo.in

Copyright: (c) the author(s), publisher and licensee Medip Academy. This is an open-access article distributed under the terms of the Creative Commons Attribution Non-Commercial License, which permits unrestricted non-commercial use, distribution, and reproduction in any medium, provided the original work is properly cited.

\begin{abstract}
Background: Evaluation of PPIUCD in terms of incidence of failure, expulsion, bleeding plv and other complication. Present study is aimed at determining the safety, efficacy, expulsion of post placental and intra cesarean insertion of intrauterine device.

Methods: Prospective analysis was carried out to collect information regarding IUCD insertion and outcome at tertiary care center for the period of three years using the hospital record that a total number of 600 mothers had postpartum intrauterine contraceptive device.

Results: Total women opted for PPIUCD 600, Followed up 560 after 1 week, 580 after 6 weeks and 400 after 6 months. Complications after 6 months 228. (pain 66, bleeding 37, expulsion 17, strings problem 7, discharge p/v 101). Conclusions: The insertion of PPIUCD is safe and effective method of contraception in the means of complication though it is a new concept for the population it is well accepted by the community though expulsion rate is somewhat high compare to conventional IUCD. it can be reduced with practice.
\end{abstract}

Keywords: Efficacy, Postpartum intrauterine contraceptive device, Safety

\section{INTRODUCTION}

Postpartum period is a very vulnerable period both for women and infant. Initiation of contraception during this period is important to prevent unintended pregnancy and short birth intervals. It can avert more than $30 \%$ of maternal deaths and $10 \%$ of child mortality. Pregnancy occurring within six months of the last delivery holds a 7.5-fold increased risk for induced abortion and a 1.6fold increased risk of stillbirth.

In a recent study of postpartum unintended pregnancies $86 \%$ resulted from non-use of contraception and $88 \%$ ended in induced abortions. ${ }^{1}$ continuation of these pregnancies is also associated with greater maternal complications and adverse perinatal outcomes. In India $65 \%$ women in the first year postpartum have an unmet need for family planning. ${ }^{2}$ Hence, providing contraception in this sensitive period is important.

Contraception method by definition mean to prevent unwanted pregnancy. According to WHO, Medical Eligibility Criteria, an IUD can be inserted in 48 hours postpartum referred to here as PPIUCD. ${ }^{2}$ A 2010 cochrane review concluded that PPIUCD are a safer and effective contraceptive method. ${ }^{3}$ Healthy timing and spacing of pregnancies have a positive effect on maternal health and newborn outcome. ${ }^{4}$ IUCD are used by only two percent of current users of contraception in India. ${ }^{5} \mathrm{~A}$ subsequent study suggested that $65 \%$ of women in the $1^{\text {st }}$ 
year of postpartum had an unmet need of family planning. ${ }^{6}$ Insertion of IUCD can be done post placental that is within $10 \mathrm{~min}$ of placental expulsion, intra cesarean section or within $48 \mathrm{hrs}$ of vaginal delivery.

\section{Opportunity for a success is excellent, because}

- Introduction of JSY has increased institutional deliveries. $^{7}$

- Labor room is attended by large no's of beneficiaries every day.

- This is particularly important for women who have limited access to medical care.

- Having just given birth, the woman is clearly not pregnant, and

- She is likely to be motivated to consider long- acting methods.

So, this study was planned to initiate contraception before hospital discharge after delivery. It is a potentially practical and cost-effective strategy to increase effective postpartum contraceptive use, given that the women are already within the health care system and motivation for contraception may be high. Studies published in nineties and early 2000 reported rates of expulsion of about 9$13 \% .^{7-9}$ However lower expulsion rates have been reported more recently with improved insertion technique..$^{10,11}$

Aims and objectives of present study were to determine retention rate of PPIUCD, to study expulsion rate of PPIUCD, to determine failure rate of PPIUCD and to determine the complication of immediate PPIUCD insertion among the patient who accepted this device.

\section{METHODS}

The study was conducted at GMERS Medical college and hospital Dharpur, Patan, Gujarat, India. From $1^{\text {st }}$ January 2015 to $31^{\text {st }}$ December 2017.women admitted and delivered at GMERS Hospital Patan were counseled. $\mathrm{Cu}$ $\mathrm{T}$ 380A was inserted as PPIUCD in accepters who fulfilled the medical eligibility criteria and had no contraindication for PPIUCD. They were followed up to 6 months postpartum.

\section{Study group}

A total of 600 women who opted for CU-T 380A in immediate post delivery period, within 10 minutes of expulsion of placenta and intra caesarean section and insertion within first 48 hours of delivery formed the study group. The women presenting to antenatal OPD were counseled about family planning and encouraged to opt for cu t insertion immediately after delivery.

The women presenting to labor room were counseled and invited to participate in the study. The inclusion and exclusion criteria were applied, and eligible women were selected. A total of 606 women who met the inclusion criteria were selected and after explaining the purpose and procedure the consent form was signed.

\section{Inclusion criteria}

- $\quad$ Age group 18 to 45 years old

- Those who gave written informed consent for PPIUCD

- No any infection

- Hemoglobin $>8 \mathrm{gm} \%$

- Those who have delivered a live baby within 10 minutes.

\section{Exclusion criteria}

- Fever during labor and delivery

- Active STDs or lower genital tract infection

- Having premature rupture of membranes 12 hours prior to admission

- Uterine abnormalities e.g. bicornuate or septate uterus, uterine myoma.

\section{Method of insertion}

In selected study group, $\mathrm{Cu} \mathrm{T}$ was inserted within 10 minutes of expulsion of placenta up to 48 hours postpartum in normal vaginal delivery, using kelly's placental forceps, taking all aseptic precautions by standard technique with adequate privacy for the woman and lighting for the service provider.

\section{Instruments}

Kelly forceps, 2 ring forceps, sim's speculam, over head lamp, povidone iodine, copper T 380A, kidney tray, cotton swabs. These all instruments supplied for the postpartum insertion of IUCD. All instruments are sterilized before use.

\section{Outcome measures}

1. Safety: In terms of pain, perforation rate, infection

2. Efficacy: In terms of expulsion and failure rates

\section{RESULTS}

Out of 600 cases majority of patient belong to 26-30 years of age group (48.66\%) (Table 1). Majority of women opting for PPIUCD are of low socio-economic class. This may be due to the fact that these women are taking services more at authors setup (Table 2). Intra cesarean insertion is more common in our study $(62.33 \%)$ compare to post placental $(30.66 \%)$ and postpartum PPIUCD consist of (7\%).

More number of patients opting PPIUCD during post LSCS and post placental PPIUCD suggest more number of counseling during antenatal period and during early labour. 
Table 1: Age distribution.

\begin{tabular}{|lll|}
\hline Age & No. of patient & $\%$ \\
\hline $18-20$ & 098 & 16.33 \\
\hline $21-25$ & 106 & 17.66 \\
\hline $26-30$ & 292 & 48.66 \\
\hline $31-35$ & 088 & 14.66 \\
\hline$>36$ & 016 & 2.66 \\
\hline Total & 600 & \\
\hline
\end{tabular}

Table 2: Socioeconomic status of patient.

\begin{tabular}{|lcc|}
\hline Socioeconomic class & No. & $\%$ \\
\hline Low & 436 & 72.66 \\
\hline Middle & 164 & 27.33 \\
\hline Total & 600 & \\
\hline
\end{tabular}

Table 3: Timing of insertion.

\begin{tabular}{|lll|}
\hline Timing of insertion & No. of patient & $\%$ \\
\hline Post Placental & 184 & 30.66 \\
\hline Intra Caesarean & 374 & 62.33 \\
\hline Post- partum & 042 & 07.00 \\
\hline Total & 600 & \\
\hline
\end{tabular}

Majority of women undergoing for LSCS opting PPIUCD $(62.33 \%)$ may be due to fear of post caesarean conception (Table 4).

Table 4: Mode of delivery.

\begin{tabular}{|lll|}
\hline Mode of delivery & No. & $\%$ \\
\hline Vaginal delivery & 226 & 37.66 \\
\hline LSCS & 374 & 62.33 \\
\hline Total & 600 & \\
\hline
\end{tabular}

In present study, out of 600 patients, more number of primipara patients. are accepting PPIUCD (45.33\%) followed by $2^{\text {nd }}$ para $(31.33 \%$ ) (Table 5).

Table 5: Parity of patient.

\begin{tabular}{|lll|}
\hline Parity & No of patient & $\%$ \\
\hline PRIMI & 272 & 45.33 \\
\hline 2 & 188 & 31.33 \\
\hline 3 & 130 & 21.66 \\
\hline 4 or more & 010 & 01.66 \\
\hline Total & 600 & \\
\hline
\end{tabular}

In present study, follow up at 1 week, 6 week and 6 months, pain was the common side effect followed by bleeding $\mathrm{p} / \mathrm{v}$ (Table 6).

No any perforation found in present study. None of the studies as per literature search have reported uterine perforation after PPIUCD insertion. Missing string was no problem at 1 week and 6 weeks follow up it was found in 7 cases at 6 months of follow up.
Table 6: Follow up and complications.

\begin{tabular}{|llll|}
\hline Complications & 1 week & 6 weeks & 6 months \\
\hline Pain & 40 & 20 & 06 \\
\hline bleeding & 18 & 15 & 04 \\
\hline expulsion & 08 & 04 & 05 \\
\hline perforation & 00 & 00 & 00 \\
\hline Missing strings & 00 & 00 & 07 \\
\hline Discharge $\mathrm{p} / \mathrm{v}$ & 32 & 46 & 23 \\
\hline
\end{tabular}

Follow up rate was about $93.33 \%$ in $1^{\text {st }}$ week (i.e. 560 patients. out of 600 patient). After 6 week, it was $96.66 \%$ and was reduced up to $66.66 \%$ at 6 months (Table 7).

Table 7: Follow up.

\begin{tabular}{|lll|}
\hline Duration & No. of patient & $\%$ \\
\hline $1^{\text {st }}$ week & $560 / 600$ & 93.33 \\
\hline $6^{\text {th }}$ week & $580 / 600$ & 96.66 \\
\hline 6 months & $400 / 600$ & 66.66 \\
\hline
\end{tabular}

In the study it was found that out of $37(n=37) \mathrm{Cu}-\mathrm{T}$ removed maximum number of $\mathrm{Cu}-\mathrm{T}$ removed due to pain. (i.e. 10) followed by bleeding p/v. (i.e. 09) patient removed $\mathrm{Cu}-\mathrm{T}$ for complain of infection was 08 and selfexpulsion rate was also 08.02 patients removed $\mathrm{Cu}-\mathrm{T}$ for tubal ligation (Table 8).

Table 8: Analysis of reason for removal.

\begin{tabular}{|lllll|}
\hline $\begin{array}{l}\text { Reason for } \\
\text { removal }\end{array}$ & 1 week & 6 weeks & $\begin{array}{l}6 \\
\text { months }\end{array}$ & Total \\
\hline Pain & 00 & 00 & 10 & 10 \\
\hline Infection & 00 & 00 & 08 & 08 \\
\hline Bleeding & 00 & 03 & 06 & 09 \\
\hline Self-expulsion & 04 & 02 & 02 & 08 \\
\hline For conceiving & 00 & 00 & - & 00 \\
\hline For tubal ligation & 00 & 00 & 02 & 02 \\
\hline Total & 04 & 05 & 28 & 37 \\
\hline
\end{tabular}

Table 9: Continuation rate.

\begin{tabular}{|llllll|}
\hline $\begin{array}{l}\text { Follow } \\
\text { up }\end{array}$ & $\begin{array}{l}\text { Cu-T } \\
\text { remo } \\
\text { ved }\end{array}$ & $\begin{array}{l}\text { Cu-T } \\
\text { self- } \\
\text { expul } \\
\text { sed }\end{array}$ & $\begin{array}{l}\text { Total } \\
\text { patient } \\
\text { follow- } \\
\text { up }\end{array}$ & $\begin{array}{l}\text { Cu-T } \\
\text { prese } \\
\text { nt }\end{array}$ & $\begin{array}{l}\text { Continu } \\
\text { ation } \\
\text { rate }\end{array}$ \\
\hline 1 week & - & 04 & 560 & 556 & $99.28 \%$ \\
\hline 6 weeks & 6 & 02 & 580 & 572 & $98.62 \%$ \\
\hline 6 months & 26 & 02 & 400 & 372 & $93.00 \%$ \\
\hline
\end{tabular}

The continuation rate i.e. number of women continuing the IUCD inserted in the postpartum was $99.28 \%$ at end of 1 st week, $98.66 \%$ at the end of $6^{\text {th }}$ week interval and $93 \%$ was at the end of 6 th month of follow up.

\section{DISCUSSION}

In a recent prospective study of follow-up of PPIUCD. In the present study total 600 patient, were followed up to 1 week, 6 week, 6 month. There were 40 patient who are 
lost to follow up at 1st week. Majority of follow-up is due to newer method and more post LSCS insertion, having fear of post-op complications.

In the present study majority of the patient opting for PPIUCD are primipara about $45.33 \%$ of patient, followed by $2^{\text {nd }}$ para $31.33 \% 3^{\text {rd }}$ para are $21.66 \%$ and multipara $1.66 \%$. This is comparable to the study by Grimes et al where they found the same. ${ }^{12}$

In the present study reproductive age 26-30 years patient comprise of about $48.66 \%$ opting PPIUCD with low socio-economic class about $72.66 \%$ of women opting PPIUCD this may be due to more number of lower socioeconomic class patients visiting our hospital.

Women undergoing LSCS seems to have greater probability of accepting postpartum IUCD possibly due to post LSCS conception fear. In our study also after LSCS acceptance rate of PPIUCD is more - $62.33 \%$ compare to normal delivery $-37.66 \%$.

In present study abdominal pain is the major complication of PPIUCD - $28.95 \%$ followed by bleeding problem $16.2 \%$ in other studies bleeding is more. ${ }^{13}$

Rate of spontaneous expulsion is 08 out of 600 which is $1.3 \%$ only. Compare to $5.6 \%$ in a clinic in Hubli, Karnataka, India, 1.6\% among 3000 women in a hospital in Paraguay and 5.6\% among women among 305 periurban Lusaka, Zambia. ${ }^{9-11}$ Expulsion of PPIUCD occur after 1st few months of insertion. Higher expulsion reported of about $9-16 \%$ in earlier studies. ${ }^{7-9}$ In a multicenter study done by Tatum et al the expulsion rates of PPIUCD were similar at 1 and 12 months in Belgium $(4 \%)$ and Chile (7\%), while in the Philippines, expulsion increased from $19 \%$ at 1 month to $28 \%$ at 12 months follow-up. ${ }^{14}$ Retention rate at $1^{\text {st }}$ week- $99.28 \%, 6^{\text {th }}$ week$98.62 \%$ and $6^{\text {th }}$ month - $93 \%$, which is more useful indicator to prevent early pregnancy and their complication. This finding in the study indicates toward a positive maternal health in future.

The symptom of irregular bleeding per vaginum was not influenced by route of insertion. The women mainly complained of excessive bleeding and were treated adequately with Nonsteroidal Anti- Inflammatory Drugs (NSAIDs) and haematinics. Shukla et al indicated a higher incidence of Menorrhagia (27.2\%) with use of CuT 200 in postpartum women. ${ }^{15}$ Gupta et al observed bleeding in $4.3 \%$ PPIUCD cases using CuT-380-A. ${ }^{16}$ Other studies using CuT-380 A have reported IUCD removal due to bleeding/pain as $6 \%$ to $8 \% .^{9,17}$ Difference in type of IUCD could possibly explain the different rates of bleeding problems.

One of the main observations at follow- up was that of undescended IUCD strings. The practice of leaving the full length of IUCD strings in uterine cavity during caesarean section and not passing it through the cervix, unlike study by Celen et al, may have had a role in the significant difference in the incidence of undescended strings in intra-caesarean insertions. ${ }^{13}$ Present technique might also be the reason for lower expulsion rates as compared to study by Celen et al $(5.3 \%)$ for intracaesarean IUCD insertions at 6 weeks of follow-up. ${ }^{17}$ Counselling the women and confirmation of IUCD in uterine cavity by ultrasound are important to reassure the women and encourage them to continue with the device.

\section{CONCLUSION}

Insertion of IUCD in immediate post-partum period is an effective, safe and convenient contraceptive intervention in both cesarean and vaginal deliveries.

The PPIUCD is safe having no reported incidence of perforation with low rate of expulsion, pelvic infection and few lost strings and further can be reduced with practice.

Authors can conclude that PPIUCD after cesarean section can be accepted well and followed up well due to fear of complication after operative delivery compare to normal vaginal delivery.

PPIUCD inserted by trained clinician principle of fundul placement using long placental forceps and timing of insertion are important in reduce in complications and expulsion. Early follow up examinations are important to identify spontaneous expulsion and provide alternate contraceptive.

Funding: No funding sources

Conflict of interest: None declared

Ethical approval: The study was approved by the Institutional Ethics Committee

\section{REFERENCES}

1. Huang YM, Merkatz R, Kang JZ, Roberts $\mathrm{K}, \mathrm{Hu}$ XY, Di Donato F, Sitruk-Ware R, Cheng LN. Postpartum unintended pregnancy and contraception practice among rural-to-urban migrant women in Shanghai. Contracept. 2012;86(6):731-8.

2. Post partum IUCD Reference Manual. New Delhi: Family Planning Division, Ministry of Health and Family Welfare, Government of India;2010.

3. Grimes DA, Lopez LM, Schulz KF, Stuart G, Van Vliet HA. Immediate post-partum insertion of intrauterine devices. Cochrane Database Syst Rev. 2015 Jun 26;(6).

4. Maternal and Child Health Integrated Program and PPFP activities, WHO Report. Available at: http:// www.k4health.org/sites/default/files/PPFPMeetings Report_formatted.pdf.

5. International Institute for Population Sciences (IIPS) and Macro International. National Family Health Survey (NFHS-3), 2005-06, India, Key Findings. Mumbai, IIPS, 2007. Available at: 
http://www.measuredhs.com/pubs/pdf/SR128/SR128 .pdf. Assess on March 14, 2013.

6. Borda M. Family Planning Needs during the Extended Postpartum Period in India. Access Family Planning Initiative Brief, 2009. Available at http://www.accesstohealth.org/toolres/pdfs/India_An alysis.pdf, on March 14, 2013.

7. Government of India. All India Summary of National Rural Health Mission Program, 2012. Available at http://www.nrhm.gov.in/monitoring/progress-ofnrhm.html. on 8 March 2013.

8. Tatum HJ, Beltran RS, Ramos R, Van Kets H, Sivin I, Schmidt FH. Immediate post-placental insertion of GYNE-T 380 and GYNE-T 380 postpartum intrauterine contraceptive devices: randomized study. Am J Obstetr Gynecol. 1996;175(5):1231-5.

9. Kittur S, Kabadi YM. Enhancing contraceptive usage by post-placental intrauterine contraceptive devices (PPIUCD) insertion with evaluation of safety, efficacy, and expulsion. Int $\mathrm{J}$ Reprod Contracep Obstetr Gynecol. 2016;1(1):26-32.

10. Araujo VB, Ortiz L, Smith J. Postpartum IUD in Paraguay. A case series of 3000 cases. Contracept. 2012;86(2):173-4.

11. Blumenthal P, Shiliya N, Neukom J, Chilambwe J, Vwalika B, Prager S, et al. Expulsion rates and satisfaction levels among postpartum IUD users in peri-urban Lusaka, Zambia. Contracept. 2011;84(3):320.

12. Grimes D, Schulz K, van Vliet H. Immediate postpartum insertion of intrauterine devices: a Cochrane review. Hum Repro. 2002:17(3):549-54.
13. Celan S, Moroy P, Sucak A, et al. Clinical outcomes of early post placental insertion of intrauterine contraception devices. Contaception.2004;69:279282.

14. Blanchard H, Mac Kaig C. ACCESS-FPProgram. 2006. Postpartum contraception. Available at: http://www.k4health.org/sites/default/files/postpartu mabortion English.pdf.

15. Shukla M, Sabuhi Qureshi C. Post-placental intrauterine device insertion-a five year experience at a tertiary care centre in north India. Indian $\mathbf{J}$ Med Res. 2012;136(3):432-5.

16. Gupta A, Verma A, Chauhan J. Evaluation of PPIUCD versus interval IUCD (380A) insertion in a teaching hospital of Western UP. Int J Reprod Contracept Obstet Gynecol. 2016;2(2):204-8.

17. Çelen Ş, Sucak A, Yıldız Y, Danışman N. Immediate postplacental insertion of an intrauterine contraceptive device during cesarean section. Contracept. 2011;84(3):240-3.

Cite this article as: Jani PS. Prospective study on outcomes of postpartum intrauterine contraceptive device including safety, efficacy and expulsion at GMERS Medical College, Dharpur-Patan, Gujarat, India. Int J Reprod Contracept Obstet Gynecol 2018;7:3131-5. 